Arch. Tierz., Dummerstorf 42 (1999) 3, 295-302

Department of Animal Breeding and Genetics, Punjab Agricultural University, Ludhiana, India

GURVINDER S. BRAH, JAGTAR S. SANDHU and MOTI L. CHAUDHARY

\title{
Variance and covariance component analysis of incubational mortality in chickens
}

\begin{abstract}
Summary
A total of 1,33,507 eggs obtained from 7864 pullets of two selected White Leghorn strains over four generations representing 304 sires and 1669 dams were incubated. The unhatched eggs were broken-open for examination of embryonic development and classified as early-dead (0-11d), late-dead (12-22d) and pips. The sire component heritabilities (\%) pooled over years in the two strains, respectively were $10.5 \pm 3.4$ and $11.0 \pm 3.2$ for total incubation mortality; $2.2 \pm 2.2$ and $5.1 \pm 2.4$ for early-dead; $6.8 \pm 3.0$ and $8.0 \pm 3.0$ for late-dead and $8.7 \pm 3.1$ and $4.8 \pm 2.4$ for pips. Total embryonic mortality as well as its three components had high genetic correlations amongst each other. However, the genetic correlations of pipping mortality with early and late mortality were weaker as compared with those of early and late mortality.
\end{abstract}

Key words: heritability, correlation, incubation, mortality, chickens

\section{Zusammenfassung}

Titel der Arbeit: Varianz- und Kovarianzkomponentenschätzungen der embryonalen Sterblichkeit von Küken

Es wurden 133507 Eier von 7864 Junghennen aus zwei Selektionslinien des Weißen Leghorns über 4 Generationen, die aus 304 Hähnen und 1669 Hennen entstammten, bebrütet. Die untersuchten Eier wurden zur Prüfung der Embryonalentwicklung drei Klassen, nämlich dem embryonalen Frühtod $(A=0.11$ Tag), dem Spättod (B=12.-22.Tag) und dem Eibruch (C) zugeordnet. Die Heritabilitätsschätzungen über Väter aus den 4 Untersuchungsjahren ergaben in den zwei Linien Werte von $10.5 \pm 3.4 \mathrm{bzw}$. $11.0 \pm 3.2$, für die Gesamtverluste, für $\mathrm{A}=2.2 \pm 2.2$ bzw. $5.1 \pm 2.4$, für $\mathrm{B}=6.8 \pm 3.0$ bzw. $8.0 \pm 3.0$ und für $\mathrm{C}=8.7 \pm 3.1$ bzw. $4.8 \pm 2.4$. Zwischen den Gesamtverlusten und den einzelnen drei Komponenten sowie zwischen diesen ergaben sich hohe genetische Korrelationen. Die genetischen Korrelationen zwischen C und A, B waren geringer als die Beziehungen zwischen A und B.

Schlüsselwörter: Heritabilität, Korrelation, Embryonalentwicklung, Sterblichkeit, Küken

\section{Introduction}

Hatchability of fertile eggs is a major component of reproductive fitness. A limited number of studies have been made to examine the extent of genetic variability for hatchability. Most of the estimates of genetic parameters in these studies were based on small sample sizes, comprising data of one or two generations and were based on discrete (all or none) nature of variables (CRITTENDEN et al., 1957; HUNTON, 1969; PRASAD et al., 1977; LILJEDAHL et al., 1979). The pattern of embryonic mortality is not uniform throughout incubation and may be conveniently divided into two or three categories. For genetic analysis, hatchability as well as embryonic 
mortality may be treated as traits of the pullets laying the eggs as well as those of the developing embryos (CRITTENDEN et al., 1957). The former is a compound trait, and is made up of two components; the first being the genetic ability of the embryo and second being the genetic contribution of the dam. Both these components may have certain heritabilities .For practical purposes, a breeder is more interested in the heritability of the compound trait as this trait permits a higher selection intensity and can be measured alongwith other economic traits. Information on genetics of embryonic mortality is even scantier (HUNTON, 1969; BRAH et al., 1991; SMITH and SAVAGE, 1992). Of these only HUNTON studied it as a trait of pullets. The study reported herein was conducted to obtain genetic parameters for components of embryonic mortality measured as trait of pullets on a continuous scale on data collected from two strains of White Leghorn over four consecutive generations.

\section{Materials and Methods}

Populations: The data used in the study were collected over four consecutive generations from two flocks of Single Comb White Leghorn (PL 1 and PL 2). The flocks had been undergoing long-term selection primarily for egg production. Some selection (independent culling levels) was also practised for egg weight (individualbasis) and liveability (family-basis). In later generations, selection for hatchability on total eggs set basis (independent culling levels) had also been practiced.

Observations: Data on fertility and hatchability were obtained for all the pullets of these populations between 32 and 40 weeks of age every year. In order to produce the fertile eggs, mass matings using 10 males for every 100 females in one pen were made. For obtaining sufficient number of eggs per pullet for measurement of fertility and hatchability, the eggs were set in three to four settings from October through January every year. While setting the eggs in the incubator, no attempt was made to grade the eggs or select them except that cracked eggs were discarded. All the eggs were marked by pullet and sire number. The eggs were candled on the 18 th day of incubation, and all candling rejects were broken open to determine whether they were infertile or contained embryos which had died at an early stage of development. The distinction between infertile and early embryonic mortality was made on the basis of macroscopic examination (HUNTON, 1969). The chicks were removed from the hatching trays after 22nd day of incubation. All dead-in-shell were removed and broken open. Embryonic mortality was divided as follows: early-dead (0-11 d); late-dead (12-22 d) and pipped eggs where the chicks had pipped the shell. The distinction between early and late mortality was, in general, straightforward except when death occurred between 8 and $12 \mathrm{~d}$ of incubation. In such cases, they were classified by visual comparison with a set of previously preserved embryos killed at various ages.

Statistical analysis: Per cent values for embryonic mortality were transformed to arcsin as per standard statistical tables (SNEDECOR and COCHRAN, 1980). The transformation of zero and hundred per cent values was done by taking into consideration the number of eggs used in the denominator of the calculation, as per the 
procedure outlined by OWEN (1962). Description of the data used is given in Table 1. Data were adjusted for hatch effects within strains by Least-squares analysis (HARVEY, 1966). For genetic analysis, embryonic mortality was considered as a trait of the pullets. The pedigreed data for each strain included sires, dams within sires and progeny within dams within sires as random effects. Heritabilities, genetic, phenotypic and environmental correlations and their standard errors were computed as per BECKER (1984) from the hierarchical set up.

Table 1

Distribution of data (Verteilung der Daten)

\begin{tabular}{ccccccccc}
\hline & \multicolumn{2}{c}{ No. of sires } & \multicolumn{2}{c}{ No. of dams } & \multicolumn{2}{c}{ No. of pullets } & \multicolumn{2}{c}{ No. of eggs set } \\
Year & PL 1 & PL 2 & PL 1 & PL 2 & PL 1 & PL 2 & PL 1 & PL 2 \\
\hline 1 & 40 & 40 & 241 & 246 & 1080 & 1232 & 14599 & 15924 \\
2 & 40 & 40 & 244 & 238 & 1116 & 1146 & 22261 & 20745 \\
3 & 40 & 40 & 192 & 178 & 794 & 805 & 15940 & 17613 \\
4 & 32 & 32 & 168 & 162 & 840 & 851 & 12801 & 13624 \\
Total & 152 & 152 & 845 & 824 & 3830 & 4034 & 65601 & 67906 \\
\hline
\end{tabular}

\section{Results and Discussion}

During the course of 4 generations, a total of 1,33,507 eggs representing 304 sires, 1669 dams and 7864 pullets were incubated for the two strains. The total incubation mortality varied between 6.8 and $15.3 \%$ over years and across strains (Table 2). The values pooled over years for PL 1 and PL 2 were 9.0 and $10.3 \%$ respectively. The values of mortality at different stages over strains and years ranged from 1.7 and $2.8 \%$ for early; 2.5 to $5.9 \%$ for late and 2.1 to $6.8 \%$ for pips.

Strain PL 2 had higher total incubation mortality as compared to strain PL 1 over all the years but the differences were significant in two of the four years. The higher total mortality of PL 2 over PL 1 was attributable, in general, to its higher mortality at all the stages. Pooled over years, strain PL 2 had significantly higher mortality at all the stages than strain PL 1. Strain PL2, was in general, early maturing and laid significantly more number of eggs of higher weight and also had higher body weights at 20 and 40 weeks of age (Table 2). Thus the strain with higher productivity level exhibited lower reproductive fitness.

Heritabilities: The heritabilities for embryonic mortality at different stages are presented in Table 3 . The estimates across generations were pooled including the negative estimate wherever it occurred. It can be argued that negative heritabilities can not occur, therefore, a logical assumption would be that when they occur their true value may be taken as zero. However, GILL and JENSEN (1968) have shown that when the true variances are very small, sampling variation may cause some of the estimates to be negative. And in such a situation, if the negative estimates are considered to be zero, the results may be an inflation of the estimate of genetic variance. 
Table 2

Performance (X \pm S.D.) of the two pedigreed strains for production and embryonic mortality traits (Leistung der zwei Linien hinsichtlich von Produktions- und Embryonensterblichkeitsmerkmalen)

\begin{tabular}{|c|c|c|c|c|c|}
\hline \multirow[b]{2}{*}{ Trait } & \multirow[b]{2}{*}{ Strain } & \multicolumn{4}{|c|}{ Year } \\
\hline & & 1 & 2 & 3 & 4 \\
\hline \multicolumn{6}{|c|}{ Production traits: } \\
\hline Egg number & PL 1 & $85.4 \pm 18.0$ & $90.8 \pm 20.0^{4}$ & $96.2 \pm 20.7^{2}$ & $89.4 \pm 20.4^{2}$ \\
\hline to 40 weeks & PL 2 & $84.0 \pm 19.3$ & $94.2 \pm 19.4^{b}$ & $102.3 \pm 21.8^{b}$ & $101.1 \pm 19.3^{b}$ \\
\hline $\begin{array}{l}\text { Age at first } \\
\text { egg (d) }\end{array}$ & $\begin{array}{l}\text { PL } 1 \\
\text { PL } 2\end{array}$ & $\begin{array}{l}168 \pm 14^{a} \\
173 \pm 17^{b}\end{array}$ & $\begin{array}{l}160 \pm 12 \\
160 \pm 12\end{array}$ & $\begin{array}{l}157 \pm 12^{\mathrm{b}} \\
154 \pm 10^{\mathrm{a}}\end{array}$ & $\begin{array}{l}162 \pm 13^{b} \\
157 \pm 12^{\mathrm{a}}\end{array}$ \\
\hline $\begin{array}{l}\text { Egg weight } \\
\text { (g) }\end{array}$ & $\begin{array}{l}\text { PL } 1 \\
\text { PL } 2\end{array}$ & $\begin{array}{l}51.8 \pm 3.6^{\circ} \\
54.0 \pm 3.2^{b}\end{array}$ & $\begin{array}{l}53.0 \pm 3.3^{\mathrm{a}} \\
55.9 \pm 3.3^{\mathrm{b}}\end{array}$ & $\begin{array}{l}52.5 \pm 3.3^{\mathrm{a}} \\
54.7 \pm 2.9^{\mathrm{b}}\end{array}$ & $\begin{array}{l}51.4 \pm 3.4^{a} \\
54.1 \pm 3.2^{b}\end{array}$ \\
\hline $\begin{array}{l}20 \text {-wk body } \\
\text { weight(g) }\end{array}$ & $\begin{array}{l}\text { PL } 1 \\
\text { PL } 2\end{array}$ & $\begin{array}{l}1079 \pm 109^{\circ} \\
1126 \pm 104^{b}\end{array}$ & $\begin{array}{l}1055 \pm 112^{\mathrm{a}} \\
1123 \pm 115^{\mathrm{b}}\end{array}$ & $\begin{array}{l}1036 \pm 103^{a} \\
1139 \pm 114^{b}\end{array}$ & $\begin{array}{l}1001 \pm 095^{a} \\
1092 \pm 105^{b}\end{array}$ \\
\hline $\begin{array}{l}40 \text {-wk body } \\
\text { weight(g) }\end{array}$ & $\begin{array}{l}\text { PL } 1 \\
\text { PL } 2\end{array}$ & $\begin{array}{l}1501 \pm 141^{a} \\
1646 \pm 155^{b}\end{array}$ & $\begin{array}{l}1459 \pm 140^{\mathrm{a}} \\
1614 \pm 158^{\mathrm{b}}\end{array}$ & $\begin{array}{l}1355 \pm 126^{\mathrm{a}} \\
1494 \pm 138^{\mathrm{b}}\end{array}$ & $\begin{array}{l}1356 \pm 135^{\mathrm{a}} \\
1482 \pm 134^{\mathrm{b}}\end{array}$ \\
\hline \multicolumn{6}{|c|}{ Embryonic mortality (\%): } \\
\hline Total & $\begin{array}{l}\text { PL } 1 \\
\text { PL } 2\end{array}$ & $\begin{array}{l}7.3 \\
7.5\end{array}$ & $\begin{array}{l}6.8^{\mathrm{a}} \\
7.5^{\mathrm{b}}\end{array}$ & $\begin{array}{l}11.7^{n} \\
15.3^{b}\end{array}$ & $\begin{array}{l}11.3 \\
11.5\end{array}$ \\
\hline Early & $\begin{array}{l}\text { PL } 1 \\
\text { PL } 2\end{array}$ & $\begin{array}{l}1.9 \\
1.7\end{array}$ & $\begin{array}{l}2.2^{\mathrm{a}} \\
2.7^{\mathrm{b}}\end{array}$ & $\begin{array}{l}2.2^{\mathrm{a}} \\
2.6^{\mathrm{b}}\end{array}$ & $\begin{array}{l}2.4 \\
2.8\end{array}$ \\
\hline Late & $\begin{array}{l}\text { PL } 1 \\
\text { PL } 2\end{array}$ & $\begin{array}{l}3.2 \\
2.6\end{array}$ & $\begin{array}{l}2.5 \\
2.7\end{array}$ & $\begin{array}{l}4.8^{\mathrm{a}} \\
5.9^{\mathrm{b}}\end{array}$ & $\begin{array}{l}4.3 \\
4.1\end{array}$ \\
\hline Pips & $\begin{array}{l}\text { PL } 1 \\
\text { PL } 2\end{array}$ & $\begin{array}{l}2.3^{a} \\
2.9^{b}\end{array}$ & $\begin{array}{l}2.1 \\
2.3\end{array}$ & $\begin{array}{l}4.7^{\circ} \\
6.8^{b}\end{array}$ & $\begin{array}{l}4.5 \\
4.6\end{array}$ \\
\hline
\end{tabular}

Letters bearing different superscripts for a trait differ significantly between strains as tested by 'c' test for production and by $\mathrm{X}^{2}$ test for embryonic mortality traits.

The sire-component heritabilities for total mortality varied between 6.4 and $24.2 \%$ over years and strains. The dam-component estimates were far more variable than the sire component estimates. The standard errors relative to the estimates were higher for the dam components than those for the sire components. There was no consistent tendency for $\mathrm{h}_{\mathrm{S}}^{2}$ to exceed $\mathrm{h}_{\mathrm{D}}^{2}$ or vice-versa in PL 1 on individual-generation basis. However, the pooled $h^{2}$ was slightly higher than the corresponding $h_{S}{ }_{S}$ for this strain. In PL 2, the dam component estimates were generally lower than the sire component estimates. The excess of sire component over the dam component in PL 2 may be due to sex-linked genetic effects (BECKER, 1984). However, such effects did not appear to be present in PL 1. CRITTENDEN et al., (1957) also did not find any consistent differences between the sire and dam component estimates for hatchability considered as pullet-trait. Contrarily, CRITTENDEN and BOHREN (1961) and HUNTON (1969) obtained slightly higher dam component estimates. The pooled estimates of the present study from sire component $(10.5 \pm 3.4$ and $11.0 \pm 3.2 \%)$ are in fair agreement with those reported by CRITTENDEN and BOHREN (1961) and HUNTON (1969) who reported sire component estimates of $16 \%$ and $16 \pm 17 \%$ respectively for hatchability of fertile eggs considered as pullet-trait. 
Table 3

Estimates of heritabilities and their standard errors (\%) (Schätzung der Heritabiltät und ihrer Standardfehler)

\begin{tabular}{|c|c|c|c|c|c|c|}
\hline \multirow[b]{2}{*}{ Year } & \multicolumn{3}{|c|}{ PL 1} & \multicolumn{3}{|c|}{ PL 2} \\
\hline & $\mathrm{h}_{s}^{2} \pm$ S. E. & $\mathrm{h}_{\mathrm{D}}^{2} \pm \mathrm{S} . \mathrm{E}$. & $\mathrm{h}_{\mathrm{S}+\mathrm{D}}^{2} \pm \mathrm{S} . \mathrm{E}$ & $h_{s}^{2} \pm$ S.E. & $\mathrm{h}_{\mathrm{D}}^{2} \pm$ S.E. & $\mathrm{h}_{\mathrm{S}+\mathrm{D}}^{2} \pm$ S.E. \\
\hline & & & \multicolumn{4}{|l|}{ Total mortality } \\
\hline 1 & $9.9 \pm 5.7$ & $0.1 \pm 10.2$ & $5.0 \pm 5.1$ & $16.9 \pm 6.8$ & $6.2 \pm 9.4$ & $11.5 \pm 5.2$ \\
\hline 2 & $7.0 \pm 5.4$ & $15.4 \pm 11.1$ & $11.2 \pm 5.3$ & $7.5 \pm 5.4$ & $13.9 \pm 10.6$ & $10.7 \pm 5.1$ \\
\hline 3 & $24.2 \pm 10.4$ & $6.2 \pm 12.8$ & $15.2 \pm 7.3$ & $6.4 \pm 6.5$ & $2.3 \pm 12.8$ & $4.4 \pm 6.1$ \\
\hline 4 & $11.8 \pm 9.5$ & $54.4 \pm 15.5$ & $33.1 \pm 7.5$ & $17.4 \pm 7.9$ & $-3.3 \pm 9.9$ & $7.0 \pm 5.5$ \\
\hline Pooled & $10.5 \pm 3.4$ & $13.9 \pm 5.9$ & $13.0 \pm 3.0$ & $11.0 \pm 3.2$ & $4.8 \pm 5.2$ & $8.8 \pm 2.7$ \\
\hline \multicolumn{7}{|c|}{ Early mortality } \\
\hline 1 & $3.4 \pm 3.3$ & $-32.6 \pm 8.4$ & $-14.6 \pm 4.0$ & $9.3 \pm 5.4$ & $9.2 \pm 9.7$ & $9.3 \pm 4.9$ \\
\hline 2 & $2.1 \pm 4.4$ & $12.9 \pm 11.0$ & $7.5 \pm 5.1$ & $0.1 \pm 3.8$ & $10.0 \pm 10.5$ & $5.2 \pm 4.8$ \\
\hline 3 & $-6.2 \pm 5.1$ & $18.3 \pm 14.7$ & $6.1 \pm 6.4$ & $6.4 \pm 6.5$ & $2.2 \pm 12.8$ & $4.3 \pm 6.1$ \\
\hline 4 & $17.9 \pm 8.1$ & $9.6 \pm 11.3$ & $13.7 \neq 6.2$ & $9.8 \pm 5.3$ & $-18.5 \pm 8.8$ & $-4.4 \pm 4.4$ \\
\hline Pooled & $2.2 \pm 2.2$ & $-5.6 \pm 5.3$ & $-0.8 \pm 2.5$ & $5.1 \pm 2.4$ & $-0.9 \pm 5.0$ & $3.1 \pm 2.4$ \\
\hline \multicolumn{7}{|c|}{ Late mortality } \\
\hline 1 & $4.0 \pm 4.5$ & $0.0 \pm 10.3$ & $2.0 \pm 4.9$ & $5.7 \pm 4.7$ & $11.3 \pm 9.9$ & $8.5 \pm 4.8$ \\
\hline 2 & $9.9 \pm 6.0$ & $15.2 \pm 11.0$ & $12.5 \pm 5.5$ & $7.5 \pm 5.7$ & $23.6 \pm 11.2$ & $15.6 \pm 5.4$ \\
\hline 3 & $24.8 \pm 10.4$ & $2.6 \pm 12.5$ & $13.7 \pm 7.2$ & $8.1 \pm 6.9$ & $3.0 \pm 12.8$ & $5.5 \pm 6.2$ \\
\hline 4 & $2.1 \pm 6.3$ & $50.9 \pm 15.5$ & $26.5 \pm 6.7$ & $17.1 \pm 9.0$ & $19.3 \pm 12.0$ & $18.2 \pm 6.4$ \\
\hline Pooled & $6.8 \pm 3.0$ & $12.5 \pm 6.0$ & $11.6 \pm 2.9$ & $8.0 \pm 3.0$ & $14.6 \pm 5.7$ & $11.6 \pm 2.8$ \\
\hline \multicolumn{7}{|c|}{ Pips } \\
\hline 1 & $9.4 \pm 6.1$ & $13.6 \pm 11.1$ & $11.5 \pm 5.5$ & $12.3 \pm 5.3$ & $-9.6 \pm 8.5$ & $1.6 \pm 4.5$ \\
\hline 2 & $7.4 \pm 5.1$ & $4.4 \pm 10.4$ & $5.9 \pm 5.1$ & $2.9 \pm 4.8$ & $23.2 \pm 11.3$ & $13.0 \pm 5.2$ \\
\hline 3 & $10.6 \pm 7.4$ & $0.1 \pm 12.7$ & $5.3 \pm 6.3$ & $-3.0 \pm 5.1$ & $-18.1 \pm 11.5$ & $-7.5 \pm 5.5$ \\
\hline 4 & $8.3 \pm 7.0$ & $19.7 \pm 12.5$ & $14.0 \pm 5.9$ & $7.0 \pm 4.5$ & $-22.1 \pm 8.6$ & $-7.6 \pm 4.1$ \\
\hline Pooled & $8.7 \pm 3.1$ & $9.3 \pm 5.8$ & $9.1 \pm 2.8$ & $4.8 \pm 2.4$ & $-9.1 \pm 4.8$ & $-0.8 \pm 2.4$ \\
\hline
\end{tabular}

Heritability estimates for early embryonic mortality in PL 1 were quite variable, and carried at least one negative estimate for each of the three components of variance. The pooled estimates were negative from dam and sire plus dam components. Even the pooled positive estimate from the sire component had standard error of equal size. GILL and JENSEN (1968) indicated that presence of negative estimates may be due to sampling error and may be indicative of the fact that the true heritability is rather low or zero. In PL 2, however, the estimates from the sire component were consistently positive with a pooled value of $5.1 \pm 2.4 \%$. These observations strengthen the contention that the true heritability of early mortality was low in PL 1 as compared to PL 2. The heritabilities obtained in the present study for early mortality are lower than those reported by HUNTON (1969) as pullet-trait though some negative estimates were also encountered by him. BRAH et al., (1991) reported sire component heritability varying between 0.1 and $8.6 \%$ in chicken while SMITH and SAVAGE (1992) reported $h^{2}$ so vary between $-7.0 \pm 8.0$ and $1.0 \pm 2.0 \%$ in turkeys by different methods of estimation, in both cases the trait being those of the embryos.

The heritabilities for late mortality over years were consistently positive in both the strains. The $\mathrm{h}_{\mathrm{S}}^{2}$ varied between 2.1 and $24.8 \%$ over years and strains. The pooled values of the present study are in fair agreement with those of SMITH and SAVAGE 
(1992). The $\mathrm{h}_{\mathrm{D}}^{2}$ exceeded $\mathrm{h}_{\mathrm{S}}^{2}$ in most of the years. The pooled estimates from the damcomponent were about two times of the corresponding sire-component estimates which indicated the presence of dominance deviations and/or maternal effects. HUNTON (1969) also noted higher dam-component than sire-component estimates for late mortality in majority of the data sets analysed.

The heritability estimates for pipping mortality were positive from the three components in PL 1 in all the years. Contrarily, in PL 2 the dam component yield negative estimates in three of the four years. The pooled sire-component estimates were $8.7 \pm 3.1$ and $4.8 \pm 2.4 \%$ in PL 1 and PL 2, respectively. There was some evidence of dominance deviations and/or maternal effects in PL 1 but not in PL 2. The pooled sire-component estimates by virtue of their standard errors were significantly different from zero.

Table 4

Genetic, phenotypic and environmental correlations among various incubation traits (Genotypische, phänotypische und Umweltkorrelationen zwischen den verschiedenen Einflußmerkmalen)

\begin{tabular}{ccccc}
\hline Trait & Strain & $\mathrm{r}_{\mathrm{G}} \pm$ S.E. & $\mathrm{r}_{\mathrm{P}}$ & $\mathrm{r}_{\mathrm{E}}$ \\
\hline Total mortality with: & & & & 0.450 \\
Early mortality & PL 1 & $0.833 \pm 0.072$ & 0.471 & 0.398 \\
& PL 2 & $0.702 \pm 0.105$ & 0.503 & 0.719 \\
Late mortality & PL 1 & $0.809 \pm 0.101$ & 0.740 & 0.705 \\
& PL 2 & $0.851 \pm 0.121$ & 0.689 & 0.716 \\
Pipping mortality & PL 1 & $0.805 \pm 0.210$ & 0.709 & 0.693 \\
& PL 2 & $0.598 \pm 0.185$ & 0.805 & 0.201 \\
Early mortality with: & & & & 0.180 \\
Late mortality & PL 1 & $0.931 \pm 0.042$ & 0.263 & 0.147 \\
Pipping mortality & PL 2 & $0.702 \pm 0.092$ & 0.271 & 0.153 \\
LL 1 & PL 2 & $0.531 \pm 0.135$ & 0.170 & \\
Pipping mortality & & $0.498 \pm 0.143$ & 0.172 & 0.210 \\
& PL 1 & & & 0.198 \\
\hline
\end{tabular}

Correlations: The genetic, phenotypic and environmental correlations among mortalities at different stages pooled over generations are presented in Table 4. The correlations involving total embryonic mortality and its components viz; early, late and pipping mortality are part and whole correlations. The tendency of automaticity involving such traits be taken into account while interpreting the estimates. However, the correlations among early, late and pipping mortality represent three independent components of total embryonic viability because these traits were expressed on the basis of fertile eggs available for that stage. Total embryonic mortality had high positive genetic, phenotypic and environmental correlations with its three component traits i.e. early, late and pipping mortality. Since the correlations of the three components with total mortality were of equal magnitude, it means that total incubation mortality is equally influenced by early, late and pipping mortality. High positive genetic correlations of total mortality with its components, are in agreement to 
those reported by HUNTON (1969).

The three components of total embryo viability had high positive genetic correlations with each other, but the phenotypic and environmental correlations, though positive, were lower than the genetic correlations. The relative size of the genetic and environmental correlations suggested that the relationships were mainly genetic in nature. However, HUNTON (1969) pointed out that due to the unusual nature of the traits being studied (i.e. the fact that once early mortality had expressed itself there is no opportunity for the incidence of mortality in the same embryos at later stages), environmental correlations may be difficult to demonstrate. It is apparent from Table 4 that the genetic correlations of pipping mortality with the early and late mortality were weaker as compared with those of early and late mortality. This implied that early and late mortality are under common genetic control whereas the genetic mechanism determining viability of the embryos after pipping is slightly different from that influencing mortality at earlier ages.

The estimates of heritability for incubation mortality indicated the presence of genetic variability within each of the two strains. The heritability of each of the three components of mortality was lower than that of the total incubation mortality. There were no consistent and large differences in heritabilities of the various components. Selection for total embryonic mortality may, therefore, be a better criterion for its genetic improvement because it may not be possible to combine the three components into a selection index due to consideration of labour and time required for obtaining the information.

\section{References}

BECKER,W.A.:

Manual of quantitative genetics. 4th edn. Academic Enterprises. Pullman,WA, U.S.A., 1984

BRAH, G.S.; SANDHU, J.S.; CHAUDHARY. M.L.:

Heritabilities estimates of components of incubation mortality in White Leghorn.Br. Poult. Sci. 32 (1991), 871-874

CRITTENDEN, L.B.; BOHREN, B.B.:

The genetic and environmental effects of hatching time, egg weight and holding time on hatchability. Poult. Sci. 40 (1961), 1736-1750

CRITTENDEN, L.B.; BOHREN, B.B.; ANDERSON, V.L.:

Genetic variance and covariance of the components of hatchability in New Hampshires. Poult.Sci. 36 (1957), 90-103

GILL, J.L.; JENSEN, E.L.:

Probability of obtaining negative estimates of heritability. Biometrics 24 (1968), 517-526

HARVEY, W.R.:

Least-squares analysis of data with unequal subclass numbers. U.S.D.A., Agricultural Research Science

HUNTON, P.: and Education Administration, 1966

Variance and covariance of hatchability and some of its components in the chicken. Br. Poult. Sci.10 (1969), 261-272

LILJEDAHL, L.E.; KOLSTAD, N; SORENSON, P.; MAIJALA, K:

Scandinavian selection and crossbreeding experiment with laying hens. I. Background and general outline. Acta Agric. Scand. 29 (1979), 273-286 


\section{OWEN, O.B:}

Handbook of statistical tables. Addison Wesley Publishing Co., Inc., 1962

PRASAD, J.; KHAN, A.G.; POULOSE, M.V.:

Genetic inferences from inter-strain crossing for hatchability and fertility in White Leghorns. Br. Poult. Sci. 18 (1977), 213-216

SMITH, E.J.; SAVAGE, T.F.:

A comparison of four methods of variance component estimation for heritability of embryonic mortality in turkeys. Poult. Sci. 71 (1992), 229-234

SNEDECOR, G.W.; COCHRAN, W.G.:

Statistical methods. 7th edn. The Iowa State University Press, Ames, Iowa, 1980

Received: 06.03.1998

Accepted: 07.01.1999

Authors' address

GURVINDER S. BRAH, B.Sc., M. Sc., PhD

JAGTAR S. SANDHU, B.Sc., M. Sc., PhD

MOTI L. CHAUDHARY, B.V.Sc., M. Sc., PhD

Department of Animal Breeding and Genetics

Punjab Agricultural University

Ludhiana-141004

India 